\title{
First Evidence of Ehrlichia minasensis Infection in Horses from Brazil
}

\author{
Lívia S. Muraro ${ }^{1}$, Aneliza de O. Souza ${ }^{2}$, Tamyres N. S. Leite ${ }^{2}$, Stefhano L. Cândido ${ }^{3}$, Andréia L. T. Melo ${ }^{4}$, \\ Hugo S. Toma ${ }^{5}\left(\mathbb{D}\right.$, Mariana B. Carvalho ${ }^{4}$, Valéria Dutra ${ }^{3}$, Luciano Nakazato ${ }^{3}$, Alejandro Cabezas-Cruz ${ }^{6} \mathbb{D}$ \\ and Daniel M. de Aguiar 1,*(D)
}

check for updates

Citation: Muraro, L.S.; Souza, A.d.O.; Leite, T.N.S.; Cândido, S.L.; Melo, A.L.T.; Toma, H.S.; Carvalho, M.B.;

Dutra, V.; Nakazato, L.;

Cabezas-Cruz, A.; et al. First

Evidence of Ehrlichia minasensis Infection in Horses from Brazil.

Pathogens 2021, 10, 265.

https://doi.org/

$10.3390 /$ pathogens 10030265

Academic Editor: Lawrence S. Young

Received: 15 January 2021

Accepted: 22 February 2021

Published: 25 February 2021

Publisher's Note: MDPI stays neutral with regard to jurisdictional claims in published maps and institutional affiliations.

Copyright: (c) 2021 by the authors Licensee MDPI, Basel, Switzerland. This article is an open access article distributed under the terms and conditions of the Creative Commons Attribution (CC BY) license (https:/ / creativecommons.org/licenses/by/ $4.0 /)$.
1 Laboratory of Virology and Rickettsial Infections, Veterinary Hospital, Federal University of Mato Grosso (UFMT), Av. Fernando Correa da Costa 2367, Cuiabá 78090-900, Brazil; liviatcho@hotmail.com

2 Veterinary Clinical Laboratory, Department of Veterinary Clinics, University of Cuiabá (UNIC), Av. Manoel José de Arruda 3100, Cuiabá 78065-900, Brazil; aneliza-oliveira@hotmail.com (A.d.O.S.); tamyres.leite@hotmail.com (T.N.S.L.)

3 Laboratory of Microbiology and Molecular Biology, Veterinary Hospital of the Faculty of Veterinary Medicine, Federal University of Mato Grosso (UFMT), Av. Fernando Correa da Costa 2367, Cuiabá 78090-900, Brazil; stefanobte@hotmail.com (S.L.C.); valdutra@cpd.ufmt.br (V.D.); lucnaka@mail.com (L.N.)

4 Veterinary of Clinical, Veterinary Medicine College, University of Cuiabá (UNIC), Av. Manoel José de Arruda 3100, Cuiabá 78065-900, Brazil; andreialtm@gmail.com (A.L.T.M.); mama_buenocarvalhos@hotmail.com (M.B.C.)

5 Veterinary Medicine Department, Federal University of Lavras (UFLA), Campus Universitário, Mailbox 3037, Lavras 37200-000, Brazil; hugo.toma@ufla.br

6 Anses, INRAE, Ecole Nationale Vétérinaire d'Alfort, UMR BIPAR, Laboratoire de Santé Animale, F-94700 Maisons-Alfort, France; alejandro.cabezas@vet-alfort.fr

* Correspondence: danmoura@ufmt.br

Abstract: The genus Ehrlichia includes tick-borne bacterial pathogens affecting humans, domestic and wild mammals. Ehrlichia minasensis has been identified in different animal species and geographical locations, suggesting that this is a widely distributed and generalist Ehrlichia. In the present study, we evaluated Ehrlichial infection in 148 Equidae presented to the Medical Clinic Department of a Veterinary Hospital from a midwestern region of Brazil. Blood samples and ticks collected from the animals were tested by Polymerase Chain Reaction (PCR) for the presence of Ehrlichia spp. A multigenic approach including Anaplasmataceae-specific (i.e., 16S rRNA, groEL, gltA) and Ehrlichiaspecific (i.e., $d s b$ and trp36) genes was used for accurate bacteria identification. Sera samples were also collected and evaluated for the detection of anti-Ehrlichia antibodies by indirect fluorescent antibody test (IFA). Possible associations between molecular and serological diagnostics and clinical and hematological manifestations were tested using chi-squared or Fisher's exact tests. Sequence analysis of the $d s b$ fragment revealed that three horses $(2.03 \%)$ were exposed to E. minasensis. Sixty-one (41.2\%) Equidae (58 equines and three mules), were seropositive for Ehrlichia spp., with antibody titers ranging between 40 and 2560. Seropositivity to ehrlichial antigens was statistically associated with tick infestation, rural origin, hypoalbuminemia and hyperproteinemia $(p \leq 0.05)$. The present study reports the first evidence of natural infection by E. minasensis in horses from Brazil.

Keywords: horse; ehrlichiosis; ticks; PCR; IFA

\section{Introduction}

Ehrlichia genus is composed of Gram-negative, obligatory intracellular bacteria transmitted by ticks. Several Ehrlichia bacteria are important pathogens, causing disease in humans and domestic and wild mammals. This genus belongs to the order Rickettsiales, family Anaplasmataceae, and has six recognized species: Ehrlichia canis, Ehrlichia chaffeensis, Ehrlichia ewingii, Ehrlichia muris, Ehrlichia ruminantium and Ehrlichia minasensis [1,2].

Equine ehrlichiosis has mostly been associated with agents of the genera Neorickettsia (i.e., N. risticii) and Anaplasma (i.e., A. phagocytophilum) [1]. In addition to these species, com- 
monly reported to cause Equine ehrlichiosis, infection by bacteria of the genus Ehrlichia has also been described in horses in the United States [3,4], and Nicaragua [5]. The genetic characterization of these Ehrlichial agents revealed their close relationship to E. ruminantium, which is an important pathogen of ruminants in Africa and the Caribbean [6], transmitted by ticks of the genus Amblyomma [7]. However, while Equine ehrlichiosis is present in Brazil [8], to date, there are no reports of E. ruminantium in Brazil [9]. Ehrlichia minasensis species has been detected in cattle [10], cervids [11] and several tick species within the genera Rhipicephalus [2,7,12,13], Amblyomma [13], Hyalomma [14,15], and Haemaphysalis [16]. Of the tick species that could vector this bacterium, Rhipicephalus microplus [17], Amblyomma hebraeum [13], Hyalomma marginatum [13,18,19] and Haemaphysalis [18] have been reported to parasitize horses, suggesting that infection by E. minasensis could be spread to other hosts, such as equines.

Despite studies on Ehrlichia infection in equine being scarce in Brazil, seropositivity to Ehrlichia antigens in horses was observed in the States of Paraná [20] and Mato Grosso [21], and the bacterial DNA was also detected in horses of Paraná [8]. Subsequent molecular surveys in Brazil suggest that the Brazilian isolate of Ehrlichia detected in horses may potentially belong to the same group as that detected in Nicaragua $[5,22]$.

Given these antecedents and the lack of studies involving Equine ehrlichiosis in Brazil, this study aims to analyze the occurrence of Ehrlichia spp. and anti-ehrlichial antibodies in horses from the state of Mato Grosso, as well as to evaluate the possible association between bacterial infection and tick parasitism, clinical manifestations, and hematological changes.

\section{Materials and Methods}

\subsection{Ethical Statement}

The animal use procedures for this study were approved by the Animal Use Ethics Committee of the University of Cuiabá (UNIC), under the protocol number 009/2018.

\subsection{Tick and Blood Sample Collection and Sera Preparation}

One hundred and forty-eight equids (horses $n=142$ and mules $n=6$ ) with a history of tick parasitism, that attended the Medical Clinic Service of a Veterinary Hospital, Mato Grosso State, Brazil, between February 2018 and April 2018, were included in the study. The animals were located in ranches of the Cuiabá municipality $\left(15^{\circ} 35^{\prime} 56^{\prime \prime} \mathrm{S}, 56^{\circ} 5^{\prime} 42^{\prime \prime} \mathrm{W}\right)$ ( $\mathrm{n}=84$ horses), Poxoreu municipality $\left(15^{\circ} 50^{\prime} 27^{\prime \prime} \mathrm{S}, 54^{\circ} 23^{\prime} 39^{\prime} \mathrm{W}\right)(\mathrm{n}=14$ horses) and the Poconé municipality $\left(16^{\circ} 7^{\prime} 2^{\prime \prime} \mathrm{S} 56^{\circ} 57^{\prime} 38^{\prime \prime} \mathrm{W}\right)(n=44$ horses and six mules)

Blood samples were collected in duplicate tubes: one with EDTA (BD Vacutainer ${ }^{\circledR}$, Franklin Lakes, NJ, USA), one for complete blood count and another for PCR testing (kept at $-80^{\circ} \mathrm{C}$ ). The other tubes, without anticoagulant (BD Vacutainer ${ }^{\circledR}$, Franklin Lakes, NJ, USA), were used for obtaining serum samples. Blood samples without anticoagulant were kept at room temperature $\left(25^{\circ} \mathrm{C}\right)$ until visible clot formation. Subsequently, the samples were centrifuged at $1500 \times g$ for $5 \mathrm{~min}$, and the obtained sera was used for biochemical and serological evaluation. Samples were kept at $-20^{\circ} \mathrm{C}$ until further use.

Ticks, when observed on the animals, were collected and kept in labeled isopropanol tubes until identification according to morphological taxonomic keys for different tick stages [23-25].

At the time of collection, an epidemiological questionnaire was applied in order to obtain variables related to the origin (urban or rural) and clinical information such as apathy, fever, mucosal pallor, bleeding, lymphadenemegaly and bloody diarrhea.

\subsection{Hematological and biochemical Analyses}

Hematological analyses were performed using the equipment pocH-100i Vet (Roche, São Paulo, SP, Brazil) and bioplus 200 (Bioplus, Barueri, SP, Brazil). Hematological (i.e., Erythrocytes 5.5-9.5 $\times 10^{6} / \mu \mathrm{L}$; hemoglobin $12-18 \mathrm{~g} / \mathrm{dL}$; hematocrit $37-55 \%$; white blood cell 6-12 $\times 10^{3} \mu \mathrm{L}$; neutrophils $2.1-9.0 \times 10^{3} \mu \mathrm{L}$; eosinophils $0.12-1.44 \times 10^{3} \mu \mathrm{L}$; lymphocytes $0.9-6.0 \times 10^{3} \mu \mathrm{L}$; monocytes $0.12-1.2 \times 10^{3} \mu \mathrm{L}$; platelets $100-350 \times 10^{3} \mu \mathrm{L}$; total plasma 
protein (PPT) 6.5-8 g/dL; fibrinogen 100-400 mg/dL) and biochemical (i.e., aspartate aminotransferase (AST) 152-294 IU/L; alkaline phosphatase (ALP) 143-395 IU/L; creatinine 1.2-1.9 mg/dL; urea nitrogen 21.4-51.3 mg/dL; total serum protein (PT) $5.2-7.9 \mathrm{~g} / \mathrm{dL}$; albumin $2.6-3.7 \mathrm{~g} / \mathrm{dL}$ and globulin $2.1-4.0 \mathrm{~g} / \mathrm{dL}$ ) reference parameters adopted by the Clinical Pathology Laboratory of the Veterinary Hospital were used to compared the obtained results. Anemia was considered when the animal showed a decrease in the number of erythrocytes, and/or a decrease in the hemoglobin and/or hematocrit content below the reference value [26].

\subsection{DNA Extraction and Molecular Detection of Anaplasmataceae Bacteria}

The wizard Genomic DNA Purification Kit (Promega, Madison, WI, USA) was used for DNA extraction from whole-blood and tick samples, following the manufacturer's instructions. Tick DNA was extracted according to Sangioni et al. [27]. In order to monitor the quality of DNA extraction in blood and ticks, samples were selected randomly to perform conventional PCR assays for the mammal endogenous gene glyceraldehyde-3-phosphate dehydrogenase (gapdh) [28] and tick mitochondrial 16S rRNA gene [29], respectively.

After DNA extraction in blood and tick samples, nested PCR assays were performed to amplify fragments of Anaplasmataceae 16S rRNA gene (360 base pair) [30], Ehrlichia spp. $d s b$ (349 bp) [10,31], and Anaplasmataceae groEL gene (445 bp) [32]. Positive samples were further evaluated by amplification of Anaplasmataceae gltA (650 bp) $[33,34]$ and Ehrlichia TRP36 genes (800 bp) [10,35]. Primers and annealing temperatures are presented in Table 1.

PCR reactions were prepared with GoTaq Green Master Mix (Promega, Madison, WI, USA) according to the manufacturer's instructions. The amplification protocol consisted of an initial denaturation step at $95^{\circ} \mathrm{C}$ for $5 \mathrm{~min}, 35$ cycles of denaturation $\left(95^{\circ} \mathrm{C}, 15 \mathrm{~s}\right)$, annealing (52 to $58{ }^{\circ} \mathrm{C}, 15 \mathrm{~s}$ ) and extension $\left(72{ }^{\circ} \mathrm{C} 1 \mathrm{~min}\right.$ ), followed by an additional extension step at $72{ }^{\circ} \mathrm{C}$ for $5 \mathrm{~min}$. Amplification products were mixed with GelRed (Uniscience, São Paulo, SP, Brazil) at 1.5\% for visualization, and run on agarose gels in horizontal electrophoresis for $20 \mathrm{~min}$ at $120 \mathrm{~V}$. DNA of Ehrlichia canis (Cuiabá strain \# 1) [35] and ultrapure water were added as positive and negative controls, respectively.

Table 1. Primers used in the study.

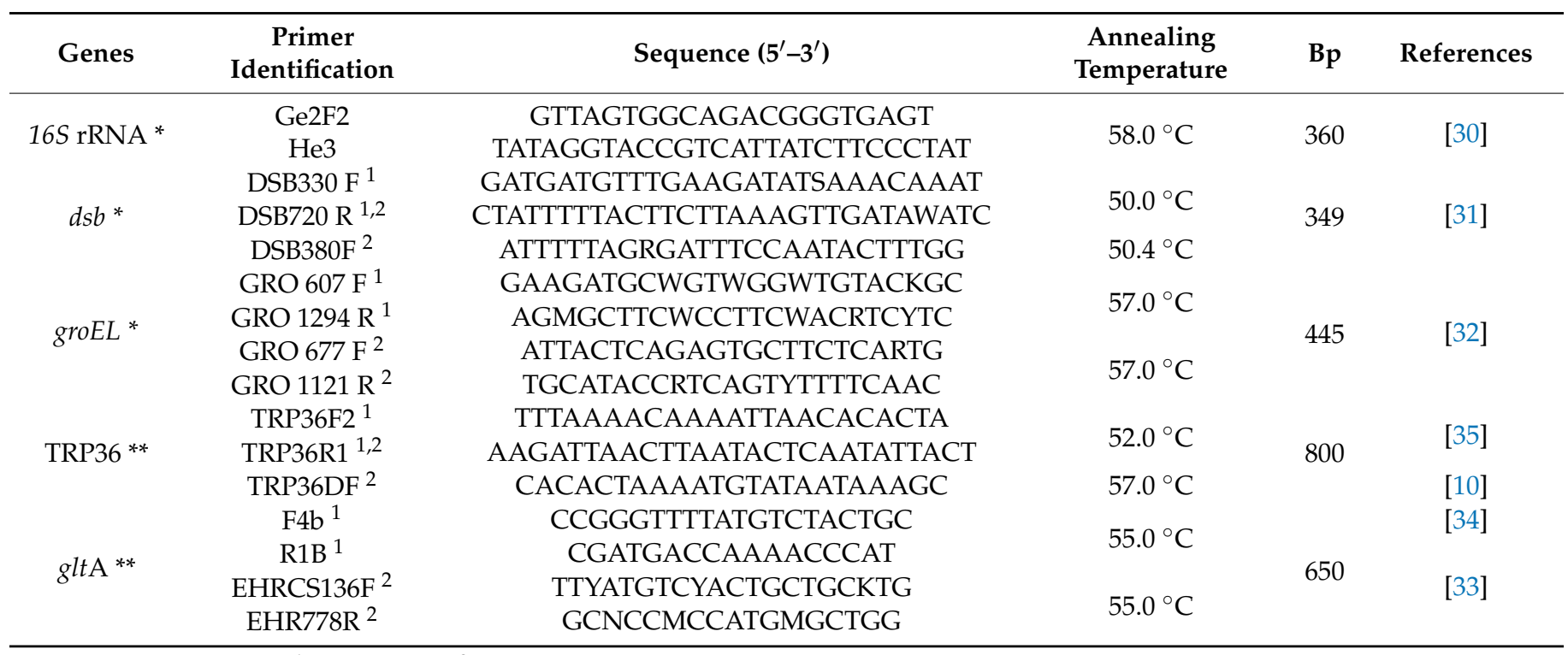

\footnotetext{
${ }^{1}$ First reaction, ${ }^{2}$ Second reaction, ${ }^{*}$ Horse and tick DNA,${ }^{* *}$ primers used in positive samples.
} 
Amplified fragments of the expected size were purified by ReliaPrep DNA Clean-Up and Concentration System ${ }^{\circledR}$ Kit (Promega, Madison, WI, USA) according to the manufacturer's instructions. Products were then subjected to nucleotide sequencing reaction using the Big Dye Kit (Applied Biosystems, Austin, TX, USA) and 3500 Genetic Analyzer automate sequencer (Applied Biosystems, Austin, TX, USA) according to the manufacturer's instructions. The sequences obtained were edited in the Geneious software (Biomatters, Auckland, New Zealand). Sequence identity analysis was performed in GenBank using the Basic Local Alignment Search Tool (BLAST).

\subsection{Serologic Analysis}

Sera samples were tested by indirect fluorescent antibody test (IFA) using E. canis Cuiabá \# 1 strain antigens. The bacterium was cultured in DH82 cells as previously described [21]. Dilutions of the sera samples at 1:40 to 1:5120 were prepared in PBS (pH 7.2) and applied to the IFA slides containing the antigen previously fixed using Acetone. Negative and positive control sera were included in each slide. Rabbit anti-equine IgG conjugated with FITIC (Sigma Diagnostics, St. Louis, Mo, USA) was added at dilution 1:800. Glycerin ( $\mathrm{pH}$ 8.5) was added to each slide to coverslip. Seroreactions were visualized under an epifluorescence microscope (Scope.A1 Zeiss) using a $40 \times$ objective.

\subsection{Statistical Analysis}

For statistical analysis, the R software (R Development Core Team, 2010) was used. Statistical evaluation was based on the association between clinical findings, laboratory tests, and any positive results for PCR or IFA, as well as for both of them. Therefore, we considered the dichotomous variable named "result", which assumed that the value of 1 in horses was characterized as positive in IFA and PCR, and the value of 0 as negative.

To calculate the association measure used for qualitative variables, the Chi-square test $(\chi 2)$ and Fisher's exact test were used when necessary, with a 95\% confidence interval. For the numerical variables, the normal distribution of the data was verified by the Kolmogovov-Smirnov test, and the Mann-Whitney test was applied due to the non-normal distribution. Differences were considered significant at $p \leq 0.05$.

\section{Results}

3.1. Health Status of the Equidae Used in the Study

From the 148 evaluated equidaes, 70 (47.4\%) were males and 78 (52.7\%) females, $142(95.9 \%)$ were horses and six $(4.1 \%)$ were mules. The clinical questionnaire revealed clinical manifestations such as apathy $(1.35 \%)$, anemia $(2.03 \%)$ and fever $(0.7 \%)$ in some animals (Table 2). No animal presented hemorrhage, diarrhea or lymphadenomegaly.

Table 2. Epidemiological and clinical data from equids evaluated for Ehrlichia infection.

\begin{tabular}{ccc}
\hline Parameters & Number of Animals & $\mathbf{\%}$ \\
\hline Origin & & \\
Rural & 65 & 43.9 \\
Urban & 83 & 56.1 \\
Clinical manifestations & 2 & 1.35 \\
Apathy & 1 & 0.7 \\
Fever & 3 & 2.03 \\
Pale mucous membranes & 0 & 0.0 \\
Bleeding & 0 & 0.0 \\
Lymphadenomegaly & 0 & 0.0 \\
Bloody diarrhea & 89 & 60.14 \\
Tick infestation & &
\end{tabular}




\subsection{Tick Infestation}

Ticks were observed and removed from 89 animals $(60.14 \%)$, of which 88 were horses and one a mule (Table 2). Seventy-eight (8.7\%) ticks were identified as Amblyomma sculptum (37 males and 41 females), 821 (91.1\%) as Dermacentor nitens (83 males, 460 females and 278 nymphs) and 2 as Rhipicephalus microplus (both males) (Table 3).

Table 3. Ticks collected from equids evaluated for Ehrlichia infection.

\begin{tabular}{cccccc}
\hline \multirow{2}{*}{ Tick Species } & Male & Female & Nymph & Total & $\%$ \\
\cline { 2 - 6 } & 37 & 41 & 0 & 78 & 8.7 \\
Amblyomma sculptum & 83 & 460 & 278 & 821 & 91.1 \\
Dermacentor nitens & 2 & 0 & 0 & 2 & 0.2 \\
Rhipicephalus microplus & &
\end{tabular}

\subsection{Hematological Parameters of Blood Samples}

The hematological changes observed were anemia in 101 (68.2\%) animals, leukocytosis in $39(26.3 \%)$, neutrophilia in $11(7.4 \%)$, lymphocytosis in $26(17.6 \%)$, plasma hyperproteinemia in $47(31.7 \%)$ and hyperfibrinogenemia in $59(40.1 \%)$. Fourteen $(9.4 \%)$ animals had azotemia, $77(52.0 \%)$ had elevated AST and only $9(6.1 \%)$ had increased ALP; hypoalbuminemia was seen in $36(24.3 \%)$ and hyperglobulinemia in 72 (48.6\%).

\subsection{Molecular Detection of Anaplasmataceae Bacteria}

The gapdh and tick mitochondrial 16S rRNA gene were consistently amplified from DNA horse and tick samples. Amplicons for $d s b$ gene were detected in blood samples of three horses $(2.03 \%)$ and were negative for the $16 \mathrm{~S}$ rRNA gene. Sequence analysis of the $d s b$ fragments revealed a sequence $99-100 \%$ identical to $E$. minasensis sequences (GenBank accession numbers: MH500007, KX258450, KT970783, KT314243, KF621012). The $d s b$ sequences generated in this study were deposited into GenBank and assigned the nucleotide accession numbers of MT232423, MT232424, MT232425. These three samples were negative for the groEL, trp36 and gltA genes. All ticks were also negative in the PCR assays.

\subsection{Detection of Anti-Ehrlichia IgG}

Anti-Ehrlichia spp. IgG was detected in 61 (41.2\%, total 148) samples (58 equines and three mules), and the antibody titers registered were $40(22.95 \%, 14$, total 61$), 80(45.9 \%, 28$, total 61$), 160(11.5 \%, 7$, total 61$), 320(13.1 \%, 8$, total 61$), 640(3.27 \%$, 2, total 61$), 1280(1.64 \%$, 2 , total 61$)$ and $2560(1.64 \%, 2$, total 61$)$. Positive samples were observed in $17(20.2 \%)$ small ranches from Cuiabá, and one (100\%) farm from Poconé and Poxoreu.

\subsection{Association between Exposure to Ehrlichia Infection and Clinical and Hematological Manifestations}

The results of $\chi 2$ test showed that three (2.03\%) PCR-positive animals were associated with the rural environment $(p=0.04)$ and hyperproteinemia $(p=0.03)$. The tendency of association was observed between PCR and hyperfibrinogemia $(p=0.06)$. Associations were found between IFA-positive animals and rural origin $(p=0.0001)$, anemia $(p=0.01)$, hyperproteinemia $(p=0.00001)$, hypoalbuminemia $(p=0.02)$, normal albuminemia $(p=0.05)$, and the presence of ticks $(p=0.03)$. Tables $4-6$ show the results of statistical analyses. 
Table 4. Associations between indirect fluorescent antibody (IFA)/polymerase chain reaction (PCR)positivity to Ehrlichia and the clinical manifestations.

\begin{tabular}{|c|c|c|c|c|c|c|}
\hline \multirow{2}{*}{ Variables } & \multicolumn{3}{|c|}{ Equidae } & \multicolumn{3}{|c|}{$x^{2}$} \\
\hline & Tested & Positive * & $\%$ & Odds Ratio & IC $95 \%$ & $p$ \\
\hline \multicolumn{7}{|l|}{ Species } \\
\hline Mule & 6 & 3 & 50 & \multirow{3}{*}{1.4} & \multirow{3}{*}{$0.18-11.16$} & \multirow{3}{*}{0.69} \\
\hline Horse & 142 & 58 & 40.8 & & & \\
\hline Sex & & & & & & \\
\hline Female & 78 & 32 & 41.0 & \multirow[b]{2}{*}{1.01} & \multirow[b]{2}{*}{$0.5-2.0$} & \multirow[b]{2}{*}{0.9} \\
\hline Male & 70 & 29 & 41.4 & & & \\
\hline \multicolumn{7}{|l|}{ Origin ** } \\
\hline Urban & 83 & 17 & 20.5 & & \multirow{2}{*}{$3.6-18.3$} & \multirow{2}{*}{$0.0001 / 0.04$} \\
\hline Rural & 65 & 44 & 67.7 & 7.9 & & \\
\hline Ticks infestation & 89 & 43 & 48.3 & 2.1 & $1.0-4.5$ & 0.03 \\
\hline Apathy & 2 & 1 & 50.0 & 1.4 & $0.01-113.7$ & 1 \\
\hline Fever & 1 & 0 & 0 & 0 & $0.0-55.57$ & 1 \\
\hline Pale mucous membranes & 3 & 2 & 66.7 & 2.9 & $0.14-173.7$ & 0.5 \\
\hline Bleeding & 0 & 0 & 0 & - & - & - \\
\hline Lymphadenomegaly & 0 & 0 & 0 & - & - & - \\
\hline Diarrhea with blood & 0 & 0 & 0 & - & - & - \\
\hline Anemia & 101 & 35 & 34.65 & - & - & 0.01 \\
\hline
\end{tabular}

Table 5. Associations between IFA/PCR-positivity to Ehrlichia and the haematological parameters.

\begin{tabular}{|c|c|c|c|c|c|}
\hline \multirow{2}{*}{ Parameter } & \multicolumn{5}{|c|}{ Equidae } \\
\hline & $N$ & $\operatorname{PCR}(\%)$ & $p$ & IFA (\%) & $p$ \\
\hline \multicolumn{6}{|c|}{ Hematocrit (\%) } \\
\hline$<37$ & 97 & $3(2.03)$ & 0.55 & $35(36.1)$ & 0.08 \\
\hline $37-55$ & 50 & $0(0)$ & 0.18 & $26(52.0)$ & 0.05 \\
\hline$>55$ & 1 & $0(0)$ & 1.0 & $0(0)$ & 1.0 \\
\hline \multicolumn{6}{|c|}{ Erythrocytes $\left(\times 10^{6} / \mu \mathrm{L}\right)$} \\
\hline$<5.5$ & 14 & $0(0)$ & 1.0 & $6(42.8)$ & 0.89 \\
\hline $5.5-9.5$ & 113 & $3(2.6)$ & 1.0 & $49(43.4)$ & 0.34 \\
\hline$>9.5$ & 21 & $0(0)$ & 1.0 & $6(28.6)$ & 0.20 \\
\hline \multicolumn{6}{|c|}{ Hemoglobin (g/dL) } \\
\hline$<12$ & 95 & $2(2.1)$ & 1.0 & $34(35.8)$ & 0.07 \\
\hline $12-18$ & 52 & $1(1.9)$ & 1.0 & $27(51.9)$ & 0.05 \\
\hline$>18$ & 1 & $0(0)$ & 1.0 & $0(78.6)$ & 1.0 \\
\hline \multicolumn{6}{|c|}{ Leukocyte count $\left(\times 10^{3} \mu \mathrm{L}\right)$} \\
\hline$<6.0$ & 2 & $0(0)$ & 1.0 & $1(50.0)$ & 1.0 \\
\hline $6.0-12.0$ & 106 & $1(0.9)$ & 0.19 & $43(40.6)$ & 0.79 \\
\hline$>12.0$ & 40 & $2(5.0)$ & 0.16 & $17(42.5)$ & 0.72 \\
\hline \multicolumn{6}{|c|}{ Neutrophils $\left(\times 10^{3} \mu \mathrm{L}\right)$} \\
\hline$<2.1$ & 0 & $0(0)$ & & $0(0)$ & \\
\hline $2.1-9.0$ & 137 & $3(2.2)$ & 1.0 & $58(42.3)$ & 0.11 \\
\hline$>9.0$ & 11 & $0(0)$ & 1.0 & $3(27.3)$ & 0.11 \\
\hline \multicolumn{6}{|c|}{ Lymphocytes $\left(\times 10^{3} \mu \mathrm{L}\right)$} \\
\hline$<0.9$ & 2 & $0(0)$ & 1.0 & $2(100.0)$ & 0.16 \\
\hline $0.9-6.0$ & 120 & $3(2.5)$ & 1.0 & $49(40.8)$ & 0.70 \\
\hline$>6.0$ & 26 & $0(0)$ & 1.0 & $10(38.5)$ & 0.89 \\
\hline \multicolumn{6}{|c|}{ Monocytes $\left(\times 10^{3} \mu \mathrm{L}\right)$} \\
\hline$<0.12$ & 97 & $2(2.1)$ & 1.0 & $41(42.3)$ & 0.72 \\
\hline $0.12-1.2$ & 50 & $1(2.0)$ & 1.0 & $20(40.0)$ & 0.85 \\
\hline$>1.2$ & 1 & $0(0)$ & 1.0 & $0(0)$ & 1.0 \\
\hline \multicolumn{6}{|c|}{ Eosinophils $\left(\times 10^{3} \mu \mathrm{L}\right)$} \\
\hline$<0.12$ & 32 & $0(0)$ & 1.0 & $12(37.5)$ & 0.62 \\
\hline $0.12-1.44$ & 115 & $3(23.5)$ & 1.0 & $49(70.6)$ & 0.52 \\
\hline$>1.44$ & 1 & $0(0)$ & 1.0 & $0(0)$ & 1.0 \\
\hline
\end{tabular}


Table 5. Cont.

\begin{tabular}{|c|c|c|c|c|c|}
\hline \multirow{2}{*}{ Parameter } & \multicolumn{5}{|c|}{ Equidae } \\
\hline & $N$ & PCR $(\%)$ & $p$ & IFA (\%) & $p$ \\
\hline \multicolumn{6}{|c|}{ Platelets $\left(\times 10^{3} \mu \mathrm{L}\right)$} \\
\hline$<100$ & 11 & $0(0)$ & 1.0 & $4(36.4)$ & 1.0 \\
\hline $100-350$ & 132 & $3(2.3)$ & 1.0 & $55(41.7)$ & 0.74 \\
\hline$>350$ & 5 & $0(0)$ & 1.0 & $2(4)$ & 1.0 \\
\hline \multicolumn{6}{|l|}{ PPT * } \\
\hline$<6.5$ & 6 & $0(0)$ & 1.0 & $1(16.7)$ & 0.40 \\
\hline $6.5-8.0$ & 95 & $0(0)$ & 0.04 & $28(29.5)$ & 0.0001 \\
\hline$>8$ & 47 & $3(6.4)$ & 0.03 & $32(68.1)$ & 0.00001 \\
\hline \multicolumn{6}{|l|}{ Fibrinogen $* *$} \\
\hline$<100$ & 0 & $0(0)$ & & $0(0)$ & \\
\hline $100-400$ & 88 & $0(0)$ & 0.08 & $31(35.2)$ & 0.13 \\
\hline$>400$ & 59 & $3(5.1)$ & 0.06 & $29(49.2)$ & 0.11 \\
\hline
\end{tabular}

* PPT-Total Plasma Protein; ${ }^{* *}$ It was not performed on a horse.

Table 6. Associations between IFA/PCR-positivity to Ehrlichia and the biochemical parameters.

\begin{tabular}{|c|c|c|c|c|c|}
\hline \multirow{2}{*}{ Biochemicals } & \multicolumn{5}{|c|}{ Equidae } \\
\hline & $N$ & PCR (\%) & $P$ & IFA (\%) & $P$ \\
\hline \multicolumn{6}{|l|}{ AST * } \\
\hline$<152$ & 6 & $0(0)$ & 1.0 & $3(50.0)$ & 1.0 \\
\hline $152-294$ & 65 & $0(0)$ & 0.41 & $27(54.0)$ & 0.61 \\
\hline$>294$ & 77 & $3(3.9)$ & 0.24 & $31(40.3)$ & 0.80 \\
\hline \multicolumn{6}{|l|}{ ALP ** } \\
\hline$<143$ & 19 & $0(0)$ & 1.0 & $7(36.8)$ & 0.67 \\
\hline $143-395$ & 120 & $3(2.5)$ & 1.0 & $52(43.3)$ & 0.27 \\
\hline$>395$ & 9 & $0(0)$ & 1.0 & $2(22.2)$ & 0.30 \\
\hline \multicolumn{6}{|l|}{ Urea nitrogen } \\
\hline$<21.4$ & 10 & $0(0)$ & 1.0 & $2(20.0)$ & 0.19 \\
\hline $21.4-51.3$ & 130 & $3(2.3)$ & 1.0 & $55(42.3)$ & 0.46 \\
\hline$>51.3$ & 8 & $0(0)$ & 1.0 & $4(50.0)$ & 0.71 \\
\hline \multicolumn{6}{|l|}{ Creatinine } \\
\hline$<1.2$ & 29 & $1(3.4)$ & 0.41 & $12(41.4)$ & 0.96 \\
\hline $1.2-1.9$ & 105 & $2(1.9)$ & 1.0 & $45(42.9)$ & 0.52 \\
\hline$>1.9$ & 14 & $0(0)$ & 1.0 & $4(28.6)$ & 0.31 \\
\hline \multicolumn{6}{|l|}{$\mathbf{P T} * * *$} \\
\hline$<5.2$ & 21 & $0(0)$ & 1.0 & $6(28.6)$ & 0.20 \\
\hline $5.2-7.9$ & 91 & $2(2.3)$ & 1.0 & $37(40.7)$ & 0.97 \\
\hline$>7.9$ & 36 & $1(2.8)$ & 0.56 & $18(50.0)$ & 0.20 \\
\hline \multicolumn{6}{|l|}{ Albumin } \\
\hline$<2.6$ & 36 & $1(2.8)$ & 0.56 & $9(25.0)$ & 0.02 \\
\hline $2.6-3.7$ & 101 & $2(2.0)$ & 1.0 & $47(46.5)$ & 0.05 \\
\hline$>3.7$ & 11 & $0(0)$ & 1.0 & $5(45.5)$ & 0.76 \\
\hline \multicolumn{6}{|l|}{ Globulin } \\
\hline$<2.6$ & 26 & $0(0)$ & 1.0 & $6(23.1)$ & 0.03 \\
\hline $2.6-4.0$ & 50 & $2(4.0)$ & 0.23 & $22(44.0)$ & 0.52 \\
\hline$>4.0$ & 72 & $1(1.4)$ & 1.0 & $33(45.8)$ & 0.26 \\
\hline
\end{tabular}

* AST-Aspartate aminotransferase; ${ }^{* *}$ ALP-Alkaline phosphatase; ${ }^{* * *}$ PT-Total serum protein.

\section{Discussion}

This paper reports, for the first time, the molecular detection of E. minasensis in horse blood in Brazil. Ehrlichia minasensis was first described in cattle from Canada [36], and later in R. microplus ticks and cattle from Brazil [7,10,36,37]. Additionally, E. minasensis has been the subject of studies on morphological and genetic characterization [38] and their distribution has been shown in recent reports in Corsica, France [14], Pakistan [15], Ethiopia [39], South Africa [13], Israel [40] and China [16]. 
Our result reinforces the hypothesis that this ehrlichial species is not restricted to cattle. Indeed, previous reports detected E. minasensis DNA in deer samples in Canada [11]. Horses can be infected while grazing on infested $R$. microplus pasture or when raised close to bovines [17]. Although no positive ticks for E. minasensis were detected, a previous study showed that populations of $A$. sculptum ticks exposed to naturally infected cattle, were negative by PCR. In contrast, $R$. microplus ticks were positive under the same conditions [12].

In this sense, even under a low frequency of $R$. microplus among Equidae in the present study, the transmission of E. minasensis by this tick species must be considered. In addition, the three positive PCR samples were from animals from a single farm, which suggests a source of infection with epidemiological relevance for horses in this site.

In this context, approximately $70 \%$ of seropositive equids were infested with at least one tick species, and these animals had 2.1 chances to obtain anti-Ehrlichia spp. antibodies (Table 4). Our result corroborates results in the USA [4], which found greater positivity in horses parasitized by ticks.

Seropositives Equidae were found in $41.2 \%$ of samples and titers of anti-Ehrlichia spp. antibodies ranging from 40 to 2560 . The presence of serum immunoglobulins against ehrlichia was previous reported in horses from the Pantanal wetlands [21], but with lower frequency and antibody titers. Serological surveys of ehrlichial infection in equids in Brazil are scarce; another study reported the presence of anti-Ehrlichia spp. antibodies in horses from a rural settlement in the Parana state, Southern Brazil, with similar IFA antibody frequencies to the present study [20].

In line with the risk observed with tick's parasitism, animals from a rural environment had a 7.9 chance of being seropositive compared to animals living in urban environments. This association reinforces the possibility of transmission by $R$. microplus ticks, since the presence of cattle in urban areas is usually insignificant when compared to their presence in the rural environment.

Hematological variables, such as anemia, hyperproteinemia and hypoalbuminemia, were associated with seropositivity for Ehrlichia spp. This result agrees with the clinical and laboratory characteristics of ehrlichiosis, whether in dogs, cattle or humans, that were usually found to have a significant hyperproteinemia [10,41,42]. In this study, positive horses had 5.2 chances of having high plasma protein compared to negative horses $(p<0.05)$. Hyperproteinemia with hyperglobulinemia is a common abnormality found in dogs with canine monocytic ehrlichiosis, due to continuous prolonged antigen stimulation [42]. In this study, hyperglobulinemia (33/61) was observed in positive equid; however, statistical significancy was not detected.

The anemia variable can be explained by the inflammatory response when serum iron is unavailable, which compromises erythropoiesis. Significant decreases in iron levels were identified in horses with local and systemic inflammatory disease [43]. Although the albumin variable showed a statistical result $(p<0.05)$, the highest observed frequency was between normal albumin values, followed by hypoalbuminemia. Thus, in the present study, this result does not reflect any laboratory parameter for equine ehrlichiosis. However, hypoalbuminemia can be observed in several situations, such as chronic liver damage, a deficit of intestinal protein absorption due to helminths, and kidney disease [44].

Increased serum fibrinogen levels were observed in both PCR/IFA-positive animals, because the highest fibrinogen levels were more frequent among the positive horses. However, these increases were not statistically significant $(p=0.06 / p=0.11)$, but the results suggest the tendency of an increase in serum fibrinogen, observed in positive animals. Elevated fibrinogen, occurring in horses, is relevant in acute phases of infections [45,46], and this result denotes an inflammatory response related to the positivity to diagnosis ehrlichiosis seen in both assays in the present study. Additionally, hyperfibrinogenemia can be justified by animals presenting plasma hyperproteinemia [26]. 


\section{Conclusions}

The present study reports the first evidence of natural infection by E. minasensis in horses in Brazil. Additionally, seropositivity against Ehrlichia antigen was associated with parasitism by ticks, rural origin and anemia. Hyperproteinemia and hyperfibrinogenemia were detected in most positive animals, reflecting inflammatory response. In the absence of a statistically significant association between the positivity of animals and clinical signs, further studies of Ehrlichia spp. infection in horses should be performed to better understand their relevance in the natural history of this ehrlichiosis in Brazil.

Author Contributions: Conceptualization, L.S.M. and D.M.d.A.; methodology, L.S.M., A.d.O.S., T.N.S.L., S.L.C., A.L.T.M., H.S.T. and M.B.C.; formal analysis, L.S.M., A.d.O.S., V.D. and L.N.; investigation, L.S.M. and A.d.O.S.; resources, D.M.d.A.; data curation, D.M.d.A. and A.C.-C.; writingoriginal draft preparation, L.S.M.; writing-review and editing, D.M.d.A. and A.C.-C.; supervision, D.M.d.A.; project administration, D.M.d.A.; funding acquisition, D.M.d.A. All authors have read and agreed to the published version of the manuscript.

Funding: This research was funded by Brazil's National Council for Scientific and Technological Development (CNPq), grant number 443923/2014-0.

Institutional Review Board Statement: The study was conducted according to the guidelines of the Declaration of Helsinki and approved by the Ethics Committee Ethics Committee of the University of Cuiabá (protocol code 009/20218 and date of approval February 23, 2018).

Informed Consent Statement: Informed consent was obtained from all subjects involved in the study.

Data Availability Statement: Not applicable.

Acknowledgments: We gratefully acknowledge the Brazil's National Council for Scientific and Technological Development $(\mathrm{CNPq})$ for their financial support and for the research productivity grant awarded to V. Dutra, L. Nakazato and D.M. Aguiar; and also for the Ministry of Education (MEC) for scholarships granted to A.O. Souza. DM Aguiar thanks God for his life and for his work for veterinary medicine. UMR BIPAR is supported by the French Government's Investissement d'Avenir program, Laboratoire d'Excellence "Integrative Biology of Emerging Infectious Diseases" (grant no. ANR-10-LABX-62-IBEID).

Conflicts of Interest: The authors declare no conflict of interest.

\section{References}

1. Dumler, J.S.; Barbet, A.F.; Bekker, C.P.J.; Dasch, G.A.; Palmer, G.H.; Ray, S.C.; Rikihisa, Y.; Rurangirwa, F.R. Reorganization of genera in the families Rickettsiaceae and Anaplasmataceae in the order Rickettsiales: Unification of some species of Ehrlichia with Anaplasma, Cowdria with Ehrlichia and Ehrlichia with Neorickettsia, descriptions of six new species combinations and designation of Ehrlichia equi and HGE agent as subjective synonyms of Ehrlichia phagocytophila. Int. J. Syst. Evol. Microbiol. 2001, 51, $2145-2165$. [CrossRef]

2. Cabezas-Cruz, A.; Zweygarth, R.; Vancova, M.; Broniszewska, M.; Grubhoffer, L.; Passos, L.M.F.; Ribeiro, M.F.B.; Alberdi, P.; de la Fuente, J. Ehrlichia minasensis sp. nov., isolated from the tick Rhipicephalus microplus. Int. J. Syst. Evol. Microbiol. 2016, 66, 1426-1430. [CrossRef]

3. Duell, J.R.; Carmichael, R.; Herrin, B.H.; Holbrook, T.C.; Talley, J.; Little, S.E. Prevalence and species of ticks on horses in Central Oklahoma. J. Med. Entomol. 2013, 50, 1330-1333. [CrossRef]

4. Carmichael, R.C.; Duell, J.R.; Holbrook, T.C.; Herrin, B.H.; Leutenegger, C.M.; O'onnor, T.P.; Little, S.R. Antibodies reactive to Ehrlichia spp. are common in Oklahoma horses. Vector Borne Zoonotic Dis. 2014, 14, 552-556. [CrossRef]

5. O'Nion, V.L.; Montilla, H.J.; Qurollo, B.A.; Maggi, R.G.; Hegarty, B.C.; Tornquist, S.J.; Breitschwerdt, E.B. Potentially novel Ehrlichia species in horses Nicaragua. Emerg. Infect. Dis. 2015, 21, 335-338. [CrossRef] [PubMed]

6. Allsopp, B.A. Natural history of Ehrlichia ruminantium. Vet. Parasitol. 2010, 167, 23-135. [CrossRef] [PubMed]

7. Cabezas-Cruz, A.; Zweygarth, R.; Ribeiro, M.F.B.; Silveira, J.A.G.; de la Fuente, J.; Grubhoffer, L.; Valdés, J.J.; Passos, L.M.F. New species of Ehrlichia isolated from Rhipicephalus (Boophilus) microplus shows an ortholog of the E. canis major immunogenic glycoprotein gp36 with a new sequence of tandem repeats. Parasit. Vectors 2012, 5, 291. [CrossRef] [PubMed]

8. Vieira, T.S.; Vieira, R.F.; Krawczak, F.S.; Soares, H.S.; Guimarães, A.M.; Barros-Filho, I.R.; Marcondes, M.; Labruna, M.B.; Biondo, A.W.; Vidotto, O. Ehrlichia sp. infection in carthorses of low-income owners, Southern Brazil. Comp. Immunol. Microbiol. Infect. Dis. 2016, 48, 1-5. [CrossRef] [PubMed]

9. Vieira, R.F.C.; Biondo, A.W.; Guimaraes, A.M.S.; Santos, A.P.; Santos, R.P.; Dutra, L.H.; Diniz, P.P.V.P.; Morais, H.A.; Messick, J.B.; Labruna, M.B.; et al. Ehrlichiosis in Brazil. Rev. Bras. Parasitol. Vet. 2011, 20, 1-12. [CrossRef] [PubMed] 
10. Aguiar, D.M.; Ziliani, T.F.; Zhang, X.; Melo, A.L.T.; Braga, I.A.; Witter, R.; Freitas, L.C.; Rondelli, A.L.H.; Luis, M.A.; Sortee, E.C.B.; et al. A novel Ehrlichia genotype strain distinguished by the TRP36 gene naturally infects cattle in Brazil and causes clinical manifestations. Ticks Tick Borne Dis. 2014, 5, 537-544. [CrossRef]

11. Lobanov, V.A.; Gajadhar, A.A.; Al-Adhami, B.; Schwantje, H.M. Molecular Study of Free-ranging Mule Deer and White-tailed Deer from British Columbia, Canada, for Evidence of Anaplasma spp. and Ehrlichia spp. Transbound. Emerg. Dis. 2012, 59, 233-243. [CrossRef]

12. Carvalho, I.T.S.; Melo, A.L.T.; Freitas, L.C.; Verçoza, R.V.; Alves, A.S.; Costa, J.S.; Chitarra, C.S.; Nakazato, L.; Dutra, V.; Pacheco, R.C.; et al. Minimum infection rate of Ehrlichia minasensis in Rhipicephalus microplus and Amblyomma sculptum ticks in Brazil. Ticks Tick Borne Dis. 2016, 7, 849-852. [CrossRef] [PubMed]

13. Iweriebor, B.C.; Mmbaga, E.J.; Adegborioye, A.; Igwaran, A.; Obi, L.C.; Okoh, A.I. Genetic profiling for Anaplasma and Ehrlichia species in ticks collected in the Eastern Cape Province of South Africa. BMC Microbiol. 2017, 17, 45. [CrossRef] [PubMed]

14. Cicculli, V.; Masse, S.; Capai, L.; de Lamballerie, X.; Charrel, R.; Falchi, A. First detection of Ehrlichia minasensis in Hyalomma marginatum ticks collected from cattle in Corsica, France. Vet. Med. Sci. 2019, 5, 243-248. [CrossRef] [PubMed]

15. Rehman, A.; Conraths, F.J.; Sauter-Louis, C.; Krücken, J.; Nijhof, A.M. Epidemiology of tick-borne pathogens in the semi-arid and the arid agro-ecological zones of Punjab province, Pakistan. Transbound. Emerg. Dis. 2019, 66, 526-536. [CrossRef]

16. Li, J.; Liu, X.; Mu, J.; Yu, X.; Fei, Y.; Chang, J.; Bi, Y.; Zhou, Y.; Ding, Z.; Yin, R. Emergence of a Novel Ehrlichia minasensis Strain, Harboring the Major Immunogenic Glycoprotein trp36 with Unique Tandem Repeat and C-Terminal Region Sequences, in Haemaphysalis hystricis Ticks Removed from Free-Ranging Sheep in Hainan Province, China. Microorganisms 2019, 7, 369. [CrossRef] [PubMed]

17. Labruna, M.B.; Kerber, C.E.; Ferreira, F.; Faccini, J.L.H.; Waal, D.T.; Gennari, S.M. Risk factors to tick infestations and their occurrence on horses in the state of São Paulo, Brazil. Vet. Parasitol. 2001, 97, 1-14. [CrossRef]

18. Tirosh-Levy, S.; Gottlieb, Y.; Apanaskevich, D.A.; Mumcuoglu, K.Y.; Steinman, A. Species distribution and seasonal dynamics of equine tick infestation in two Mediterranean climate niches in Israel. Parasit. Vectors 2018, 11, 546. [CrossRef]

19. Grandi, G.; Chitimia-Dobler, L.; Choklikitumnuey, P.; Strube, C.; Springer, A.; Albihn, A.; Jaenson, T.G.T.; Omazic, A. First records of adult Hyalomma marginatum and H. rufipes ticks (Acari: Ixodidae) in Sweden. Ticks Tick Borne Dis. 2020, 11, 101403. [CrossRef]

20. Vieira, R.F.; Vieira, T.S.; Nascimento, D.A.; Martins, T.F.; Krawczak, F.S.; Labruna, M.B.; Chandrashekar, R.; Marcondes, M.; Biondo, A.W.; Vidotto, O. Serological survey of Ehrlichia species in dogs, horses and humans: Zoonotic scenery in a rural settlement from southern Brazil. Rev. Inst. Med. Trop. São Paulo 2013, 55, 335-340. [CrossRef] [PubMed]

21. Barros, E.M.; Braga, I.A.; Santos, L.G.F.; Ziiliane, T.F.; Melo, A.L.T.; Borges, A.M.C.M.; Silva, L.G.; Aguiar, D.M. Detecção de Theileria equi e Babesia caballi e anticorpos anti-Ehrlichia spp. em equídeos do Pantanal Mato-Grossense, Brasil. Arq. Bras. Med. Vet. Zootec. 2015, 67, 716-722. [CrossRef]

22. Vieira, T.S.W.J.; Qurollo, B.A.; Mongruel, A.C.B.; Baggio, R.A.; Vidotto, O.; Breitschwerdt, E.B.; Vieira, R.F.C. Potentially same novel Ehrlichia species in Horses in Nicaragua and Brazil. Emerg. Infect. Dis. 2018, 24, 953. [CrossRef]

23. Barros-Battesti, D.M.; Arzua, M.; Bechara, G.H. Carrapatos de importância médico-veterinária da Região Neotropical: Um guia ilustrado para identificação de espécies; Vox/International Consortium on Ticks and Tick-borne Diseases/Butantan: São Paulo, SP, Brazil, 2006; 223p.

24. Martins, T.F.; Onofrio, V.C.; Barros-Battesti, D.M.; Labruna, M.B. Nymphs of the genus Amblyomma (Acari: Ixodidae) of Brazil: Descriptions, redescriptions, and identification key. Ticks Tick Borne Dis. 2010, 1, 75-99. [CrossRef]

25. Martins, T.F.; Barbieri, A.R.; Costa, F.B.; Terassini, F.A.; Camargo, L.M.; Peterka, C.R.; Pacheco, R.C.; Dias, R.A.; Nunes, P.H.; Marcili, A.; et al. Geographical distribution of Amblyomma cajennense (sensu lato) ticks (Parasitiformes: Ixodidae) in Brazil, with description of the nymph of A. cajennense (sensu stricto). Parasites Vectors 2016, 9, 186. [CrossRef] [PubMed]

26. Jain, N.C. Essentials of Veterinary Hematology; Lea \& Febiger: Philadelphia, PA, USA, 1993; 417p.

27. Sangioni, L.A.; Horta, M.C.; Vianna, M.C.; Gennari, S.M.; Soares, R.M.; Galvão, M.A.; Schumaker, T.T.; Ferreira, F.; Vidotto, O.; Labruna, M.B. Rickettsial Infection in Animals and Brazilian Spotted Fever Endemicity. Emerg. Infect. Dis. 2005, 11, 265-270. [CrossRef]

28. Braga, I.A.; Ramos, D.G.S.; Marcili, A.; Melo, A.L.T.; Taques, I.I.G.G.; Amude, A.M.; Chitarra, C.S.; Nakazato, L.; Dutra, V.; Pacheco, R.C.; et al. Molecular detection of tick-borne protozoan parasites in a population of domestic cats in midwestern Brazil. Ticks Tick. Borne Dis. 2012, 7, 1004-1009. [CrossRef] [PubMed]

29. Mangold, A.J.; Bargues, M.D.; Mas-Coma, S. Mitochondrial 16S rDNA sequences and phylogenetic relationships of species of Rhipicephalus and other tick genera among Metastriata (Acari: Ixodidae). Parasitol. Res. 1998, 84, 478-484. [CrossRef] [PubMed]

30. Aguiar, D.M.; Hagiwara, M.K.; Labruna, M.B. In vitro isolation and molecular characterization of an Ehrlichia canis strain from São Paulo, Brazil. Braz. J. Microbiol. 2008, 39, 489-493. [CrossRef] [PubMed]

31. Almeida, A.P.; Souza, T.D.; Marcili, A.; Labruna, M.B. Novel Ehrlichia and Hepatozoon agents infecting the crab-eating fox (Cerdocyon thous) in southeastern Brazil. J. Med. Entomol. 2013, 50, 640-646. [CrossRef] [PubMed]

32. Kim, C.M.; Kim, S.W.; Kim, D.M.; Yoon, N.R.; Jha, P.; Jang, S.J.; Ahn, Y.J.; Lim, D.; Lee, S.H.; Hwang, S.D.; et al. Case Report: Polymerase Chain Reaction Testing of Tick Bite Site Samples for the Diagnosis of Human Granulocytic Anaplasmosis. Am. J. Trop. Med. Hyg. 2017, 97, 403-406. [CrossRef] 
33. Gofton, A.W.; Doggett, S.; Ratchford, A.; Ryan, U.; Irwin, P. Phylogenetic characterisation of two novel Anaplasmataceae from Australian Ixodes holocyclus ticks: "Candidatus Neoehrlichia australis" and "Candidatus Neoehrlichia arcana". Int. J. Syst. Evol. Microbiol. 2016, 66, 4256-4261. [CrossRef] [PubMed]

34. Müller, A.; Monti, G.; Otth, C.; Sepúlveda, P.; Bittencourt, P.; Nachum-Biala, Y.; Gutiérrez, R.; Harrus, S. “Candidatus Neoehrlichia chilensis" sp. nov.: Molecular detection and characterization of a novel Anaplasmataceae in wild rodents from Valdivia, southern Chile. Transbound. Emerg. Dis. 2018, 65, 357-362. [CrossRef]

35. Aguiar, D.M.; Zhang, X.; Melo, A.L.; Pacheco, T.A.; Meneses, A.M.; Zanutto, M.S.; Horta, M.C.; Santarém, V.A.; Camargo, L.M.; McBride, J.W.; et al. Genetic diversity of Ehrlichia canis in Brazil. Vet. Microbiol. 2013, 164, 315-321. [CrossRef]

36. Gajadhar, A.A.; Lobanov, V.; Scandrett, W.B.; Campbell, J.; Al-Adhami, B. A novel Ehrlichia genotype detected in naturally infected cattle in North America Vet. Parasitol. 2010, 173, 324-329. [CrossRef]

37. Aguiar, D.M.; Junior, J.P.A.; Nakazato, L.; Bard, E.; Aguilar-Bultet, L.; Vorimore, F.; Popov, V.L.; Colodel, E.M.; Cabezas-Cruz, A. Isolation and Characterization of a Novel Pathogenic Strain of Ehrlichia minasensis. Microorganisms 2019, 7, 528. [CrossRef]

38. Cabezas-Cruz, A.; Zweygarth, E.; Broniszweska, M.; Passos, L.M.F.; Ribeiro, M.F.B.; Manrique, M.; Tobes, R.; de la Fuente, J. Complete genome sequence of Ehrlichia mineirensis, a novel organism closely related to Ehrlichia canis with a new host association. Genome Announc. 2015, 3, 1-2. [CrossRef]

39. Hailemariam, Z.; Krücken, J.; Baumann, M.; Ahmed, J.S.; Clausen, P.-H.; Nijhof, A.M. Molecular detection of tick-borne pathogens in cattle from Southwestern Ethiopia. PLOS ONE 2017, 12, e0188248. [CrossRef]

40. Thomson, K.; Yaaran, T.; Belshaw, A.; Curson, L.; Tisi, L.; Maurice, S.; Kiddle, G. A new TaqMan method for the reliable diagnosis of Ehrlichia spp. in canine whole blood. Parasit. Vectors 2018, 11, 350. [CrossRef] [PubMed]

41. Dawson, J.E.; Anderson, B.E.; Fishbein, D.B.; Sanchez, J.L.; Goldsmith, C.S.; Wilson, K.H.; Duntley, W. Isolation and characterization of an Ehrlichia sp.: From a patient diagnosed with human ehrlichiosis. J. Clin. Microbiol. 1991, 29, 2741-2745. [CrossRef] [PubMed]

42. Harrus, S.; Waner, T.; Avidar, Y.; Bogin, E.; Peh, H.; Bark, H. Serum protein alterations in canine ehrlichiosis. Vet. Parasitol. 1996, 66, 241-249. [CrossRef]

43. Borges, A.S.; Divers, T.J.; Stokol, T.; Mohammed, O.H. Serum iron and plasma fibrinogen concentrations as indicators of systemic inflammatory diseases in horses. J. Vet. Inter. Med. 2007, 21, 489-494. [CrossRef]

44. Kaneko, J.J.; Harvey, J.W.; Bruss, M.L. Clinical Biochemistry of Domestic Animals, 5th ed.; Academic Press: London, UK, 1997; 932p.

45. Hultén, C.; Demmers, S. Serum amyloid A (SAA) as an aid in the management of infectious disease in the foal: Comparison with total leucocyte count, neutrophil count and fibrinogen. Equine Vet. J. 2002, 34, 693-698. [CrossRef] [PubMed]

46. Jacobsen, S.; Andersen, P.H. The acute phase protein serum amyloid A (SAA) as a marker of inflammation in horses. Equine Vet. Educ. 2007, 19, 38-46. [CrossRef] 